\title{
PERANCANGAN APLIKASI SISTEM PAKAR KEPRIBADIAN UNTUK MENGIDENTIFIKASI SIFAT DAN KEPRIBADIAN SISWA SMKN 1 CILEUNGSI BERBASIS JAVA NETBEANS
}

\author{
Alvian Dahfin Pradana ${ }^{1}$, Barda Hudaya ${ }^{2}$ \\ ${ }^{1,2}$ Program Studi Teknik Informatika, Fakultas Teknik dan Ilmu Komputer, \\ Universitas Indraprasta PGRI \\ Jalan Raya Tengah No 80, Kelurahan Gedong, Pasar Rebo, Jakarta Timur \\ viandahfin@gmail.com ${ }^{1}$, b4rd4.hoedaya@gmail.com ${ }^{2}$
}

\begin{abstract}
Abstrak
Tujuan penelitian adalah untuk mengetahui bagaimana prosedur tes kepribadian yang sedang berjalan di SMKN 1 Cileungsi dan membantu sekolah tersebut dalam melakukan tes kepribadian sehingga dapat menentukan kepribadian siswa yang mengikuti tes dan menyajikan pengolahan data peserta dan data penguji dengan cepat dan akurat sehingga dapat menghasilkan informasi yang tepat dan sesuai dengan kebutuhan.Metode penelitian yang digunakan dalam perancangan aplikasi ini adalah metode Grounded Research selain itu juga melakukan observasi dan wawancara langsung dengan atasan perihal untuk menyesuaikan keinginan dalam perancangan aplikasi sistem pakar kepribadian.Dalam hal lain juga mendeskripsikan penelitian dengan menggunakan referensi serta buku dan media lainnya yang memuat informasi yang dibutuhkan. Aplikasi sistem pakar kepribadian ini diharapkan dapat membantu penggunanya dalam melakukan tes psikologi dengan cepat, efektif dan efisien.
\end{abstract}

Kata Kunci : Perancangan, Aplikasi, Sistem Pakar Kepribadian, Java Netbenas, SMKN 1 Cileungsi

\begin{abstract}
The purpose of the study was to find out how the personality test procedure is currently running at SMKN 1 Cileungsi and assist the school in conducting personality tests so that it can determine the personality of the students taking the test and present the processing of participant data and examiner data quickly and accurately so that it can produce the right information. and in accordance with the needs. The research method used in designing this application is the Grounded Research method, besides that it also conducts direct observations and interviews with superiors regarding to adjust the wishes in designing the personality expert system application. In other cases, it also describes research using references and books and other media containing the required information. This personality expert system application is expected to assist users in conducting psychological tests quickly, effectively and efficiently.
\end{abstract}

Keyword : Design, Application, Personality Expert System, Java Netbenas, SMKN 1 Cileungsi

\section{PENDAHULUAN}

Pada saat ini aplikasi teknologi sangat dibutuhkan, terutama dalam proses tes psikologi. Era teknologi sudah banyak berkembang terutama komputer sebagai salah satunya, untuk itu dengan memanfaatkan dan mengembangkan teknologi sudah menjadi bagian dalam dunia kerja. Salah satu yang memperoleh manfaat dari perkembangan teknologi ini adalah SMKN 1 Cileungsi ini merupakan sebuah sekolah menengah kejuruan berpredikat negeri. Bagi sekolah yang berpredikat negeri, SMKN 1 Cileungsi masih kesulitan mengolah data yang kurang akurat sehingga seringkali menimbulkan berbagai macam masalah. Yaitu terjadinya kesalahan dalam pengisian data peserta, kesulitan dalam membuat tes dan pembuatan laporan pada saat tes telah dilaksanakan. Kemudian terjadinya kesulitan dalam memeriksa jawaban tes dan sulitnya menilai tes karena menumpuknya jawaban-jawaban peserta. Dalam melakukan tes kepribadian yang masih manual akan membutuhkan waktu yang lama. Karena di era teknologi jika masih menggunakan cara manual akan memperlambat proses dan tidak efisien, sehingga dibutuhkannya tes kepribadian yang cepat dan tepat, lalu menggabungkan teknologi dengan sekolah untuk membuat suatu pekerja menjadi lebih efisien dan efektif sehingga memudahkan kegiatan tes didalam SMKN 1 Cileungsi agar 
menjadi lebih baik. Dalam kesempatan ini penulis tertarik membuat aplikasi dengan judul "Perancangan Aplikasi Sistem Pakar Kepribadian Untuk Mengidentifikasi Sifat dan Kepribadian Siswa SMKN 1 Cileungsi Berbasis Java Netbeans".Penulis berharap semoga aplikasi ini dapat memudahkan pengguna dalam melakukan tes kepribadian yang lebih cepat, tepat dan efisien.Perancangan merupakan penggambaran, perencanaan dan pembuatan sketsa atau pengaturan dari beberapa elemen yang terpisah ke dalam suatu kesatuan yang utuh dan berfungsi(Syifaun Nafisah, 2010:2). Sistem dapat diartikan sebagai sekelompok atau sekelompok elemen, komponen atau variabel. Elemen-elemen, komponen atau variabel tersebut terorganisir, berinteraksi, saling bergantung dan terintegrasi. Sistem juga merupakan sekumpulan elemen yang saling terkait dan saling bergantung yang bekerja sama untuk memproses masukan (input) yang diselesaikan dalam sistem dan mengolah masukan tersebut untuk menghasilkan keluaran (output) yang diinginkan (Subhan, 2012). Aplikasi adalah subkelompok perangkat komputasi yang menggunakan kemampuan langsung komputer untuk melakukan tugas yang diinginkan oleh pengguna Nazrudin Safaat H (2011: 9). Sistem pakar terdiri dari dua bagian utama, lingkungan pengembangan dan lingkungan konsultasi (T Sutojo, Edy Mulyanto 2011). Java adalah bahasa pemrograman untuk membuat konten yang berfungsi di halaman web, juga dapat berjalan di komputer Asropudin (2013:52).

\section{PENELITIAN RELEVAN}

Dalam melakukan penelitian tentang Perancangan aplikasi sistem pakar kepribadian untuk mengidentifikasi sifat dan kepribadian siswa SMKN 1 Cileungsi Berbasis Java Netbeans adalah hasil dari pemikiran penulis itu sendiri dengan adanya sumber penelitian sebelumnya yang pernah dilakukan oleh (Yossi, 2018) dalam penelitian ini berisi tentang model rancangan aplikasi sistem pakar serta untuk menunjukkan hasil sistem komputerisasi dalam data kepada masyarakat.

Penelitian yang dilakukan oleh (Budi, 2011) Aplikasi Sistem Pakar Berbasis Web Untuk Diagnosa Penyakit Gigi dan Mulut bertujuan untuk memudahkan user dalam melakukan proses konsultasi, karena pertanyaan gejala yang diajukan hanya terkait penyakit yang dialami.

\section{METODE PENELITIAN}

Penelitian ini menggunakan metode grounded research yaitu suatu metode penelitian yang mendasarkan diri kepada fakta dan menggunakan analisa perbandingan bertujuan untuk mengadakan generalisasi empiris, menetapkan konsep-konsep, membuktikan teori dan mengembangkan teori di mana pengumpulan data dan analisa data berjalan pada waktu yang bersamaan (Sugiyono, 2012).Wawancara adalah suatu kegiatan dilakukan untuk mendapatkan informasi secara langsung dengan mengungkapkan pertanyaan-pertanyaan pada para responden. Wawancara bermakna berhadapan langsung antara interview dengan responden, dan kegiatannya dilakukan secara lisan (Subagyo, 2011). Observasi dan penelitian lapangan,metode ini dilakukan dengan cara pengamatan langsung terhadap tempat SMKN 1 Cileungsi, internet dan wawancara dengan guru dan kepala sekolah dalam memperoleh data-data secara langsung pada objek yang diperlukan.Wawancara,metode ini dilakukan melalui tatap muka langsung dan tanya jawab dengan pihak terkait yang berhubungan dengan penelitian atau sumber data. Serta mengajukan pertanyaanpertanyaan serta melakukan wawancara kepada guru dan kepala sekolah SMKN 1 Cileungsi. Dengan metode ini data dapat diperoleh secara langsung oleh narasumber.

\section{HASIL DAN PEMBAHASAN}

\section{Analisis Permasalahan}

Dari hasil penelitian yang penulis lakukan maka penulis dapat menganalisa permasalahan yang ada pada proses tes kepribadian di SMKN 1 Cileungsi yaitu, tidak adanya suatu aplikasi tes psikologi di SMKN 1 Cileungsi. Kurang efektifnya proses tes kepribadian yang dilakukan di SMKN 1 Cileungsi. Informasi yang terkait dengan tes kepribadian tidak dapat dengan mudah diakses oleh 
para guru di SMKN 1 Cileungsi. Proses tes kepribadian tidak dapat dilakukan dengan cepat dan mudah sehingga menimbulkan kesalahan.

\section{Alternatif Penyelesain Masalah}

Alternatif penyelesaian masalah yang akan penulis lakukan untuk mempermudah tes kepribadian di SMKN 1 Cileungsi, dalam memperolah informasi tentang pengolahan data di SMKN 1 Cileungsi. Sehingga proses tes kepribadian dan penyampaian informasi dapat dilakukan dengan cepat, efisien, akurat.

\section{Diagram Konteks Yang Diusulkan}

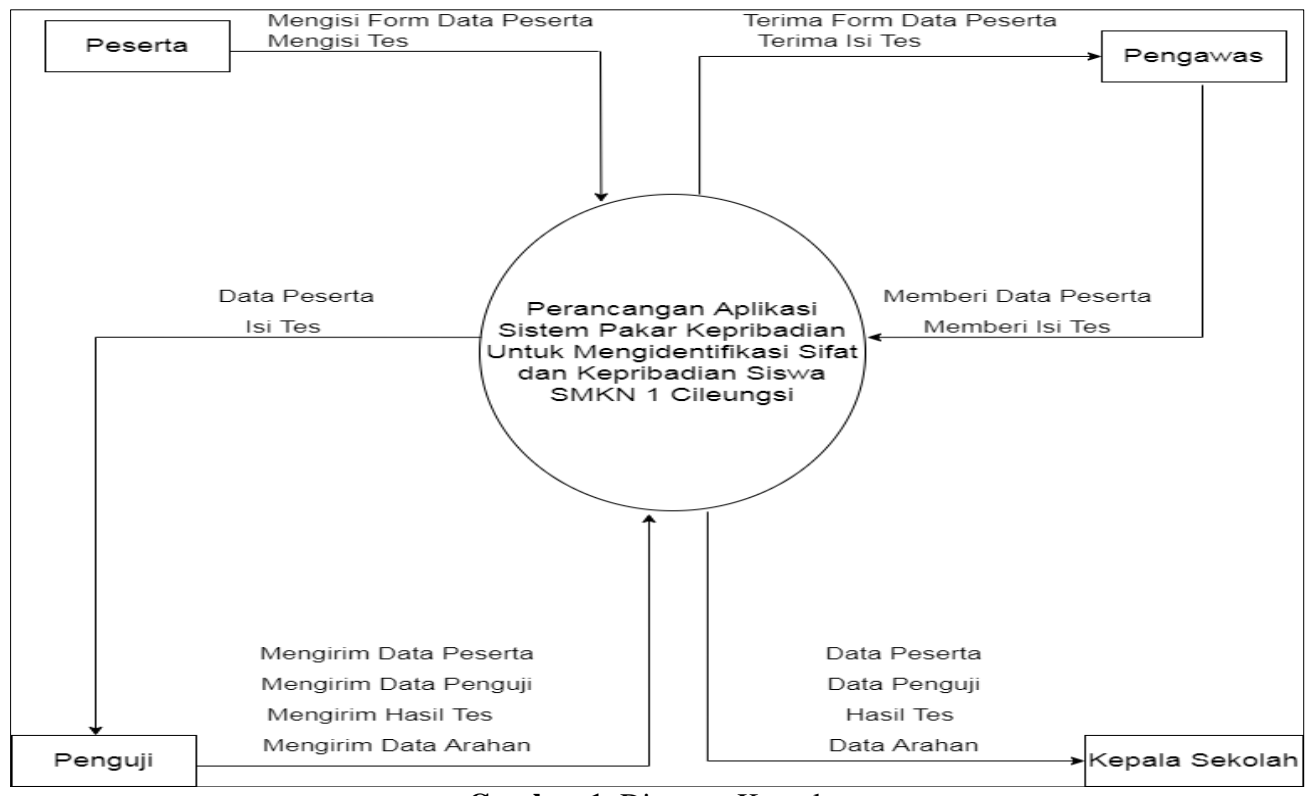

Gambar 1. Diagram Konteks

\section{Entity Relationship Diagram (ERD)}

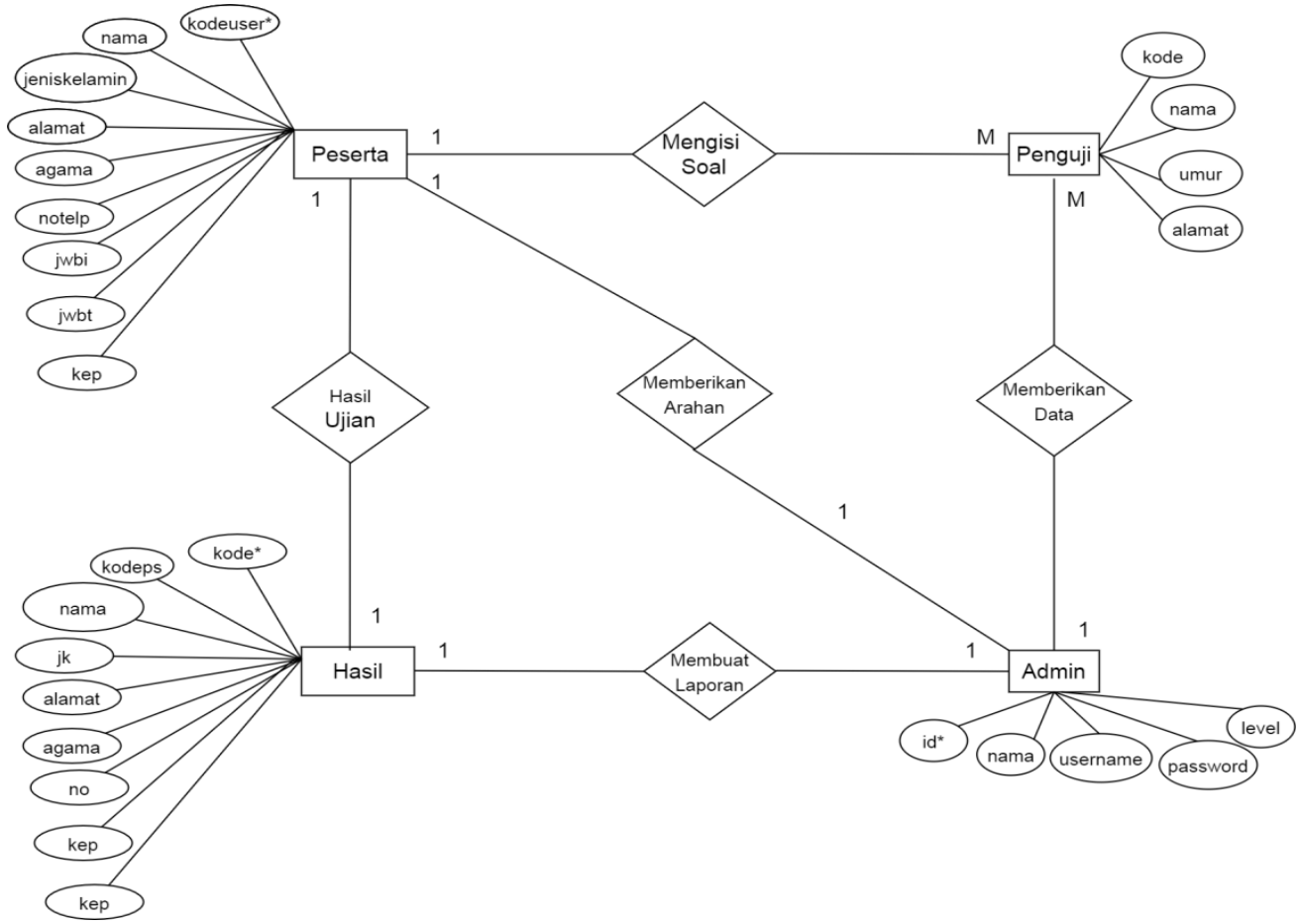

Gambar 2. Diagram Entity Relationship Diagram ERD 


\section{Tampilan Layar}

Berikut tahap implementasi dan pengujian pada software program yang telah di buat dengan bahasa pemrogram java.

\section{Tampilan Login}

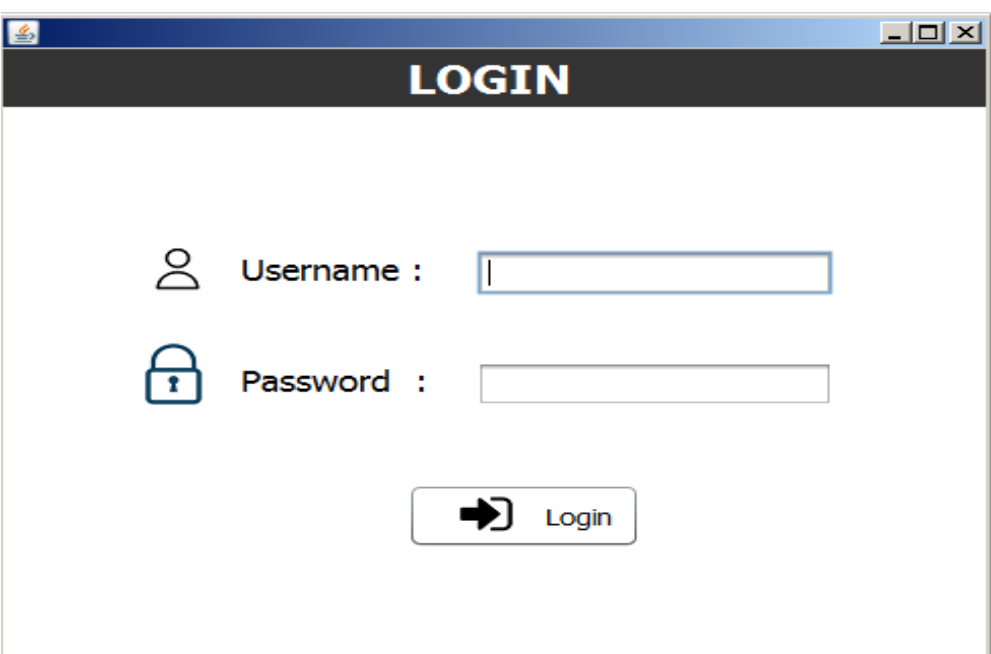

Gambar 3. Tampilan Login

Tampilan ini merupakan halaman awal pada saat aplikasi dijalankan, menu ini berfungsi untuk masuk keadalam menu utama.

\section{Tampilan Menu Utama}

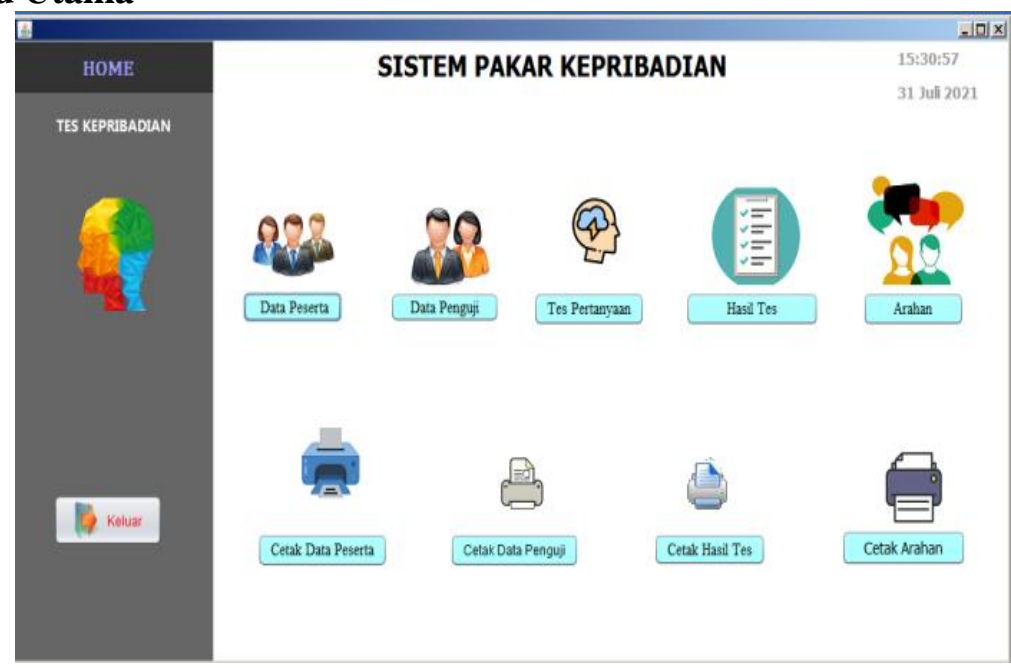

Gambar 4. Tampilan Menu Utama

Tampilan menu utama dari aplikasi yang dihasilkan dari penelitian ini untuk memilih menu sesuai kegiatan yang dibutuhkan dengan memilih list button yang sudah tersedia. 


\section{Tampilan Data Peserta}

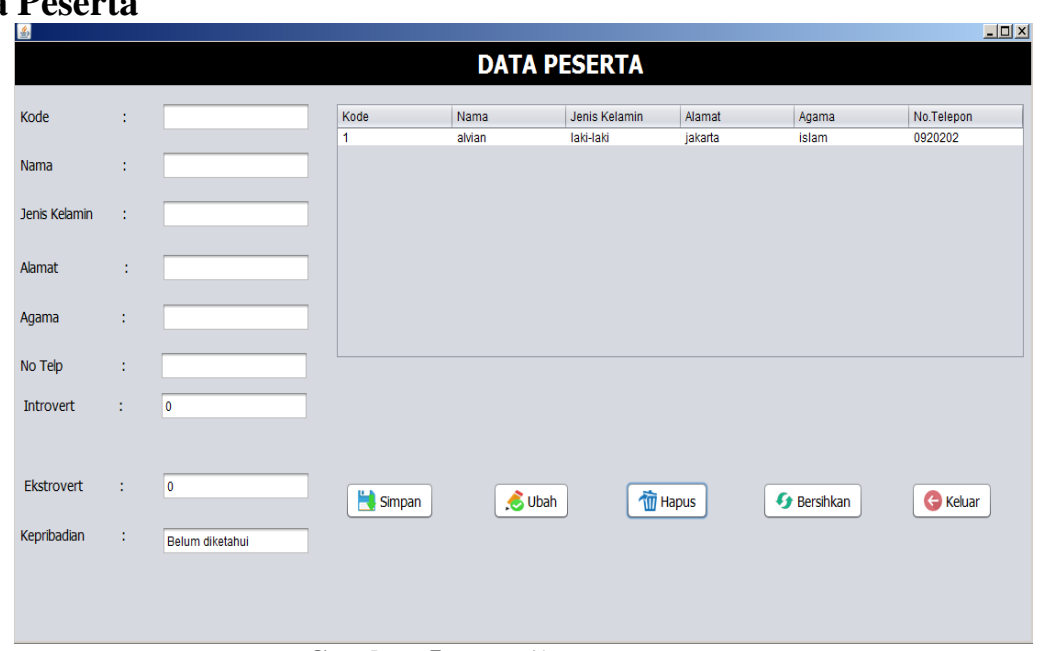

Gambar 5. Tampilan Data Peserta

Pada tampilan ini merupakan rancangan tampilan form data peserta. Berfungsi untuk memasukkan data-data peserta.

\section{Tampilan Data Penguji}

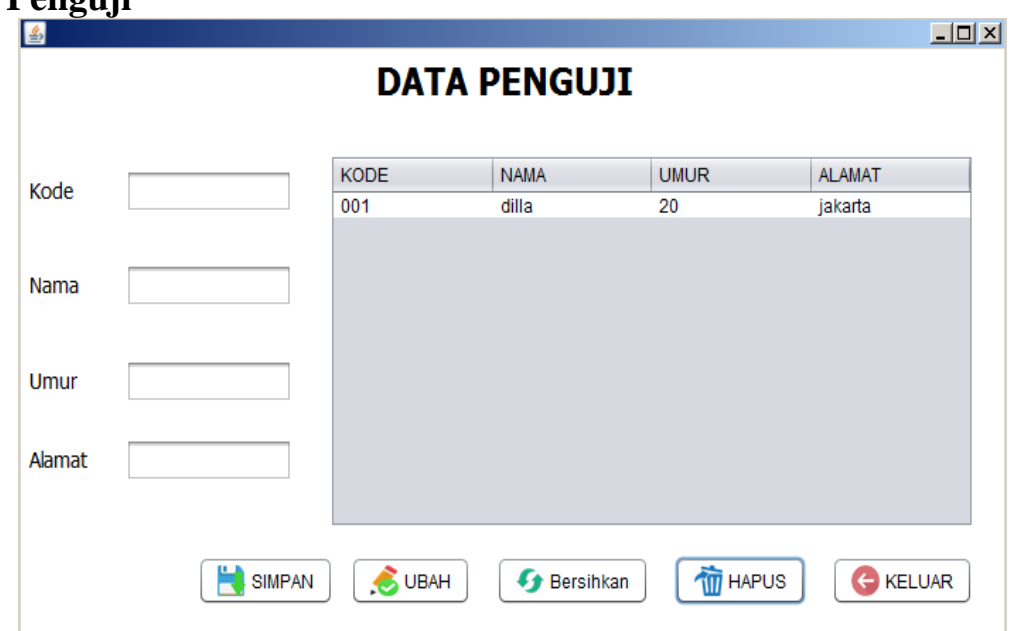

Gambar 6. Tampilan Data Penguji

Pada tampilan ini merupakan rancangan tampilan form data penguji. Berfungsi untuk memasukkan data-data penguji.

\section{Tampilan Tes Pertanyaan}

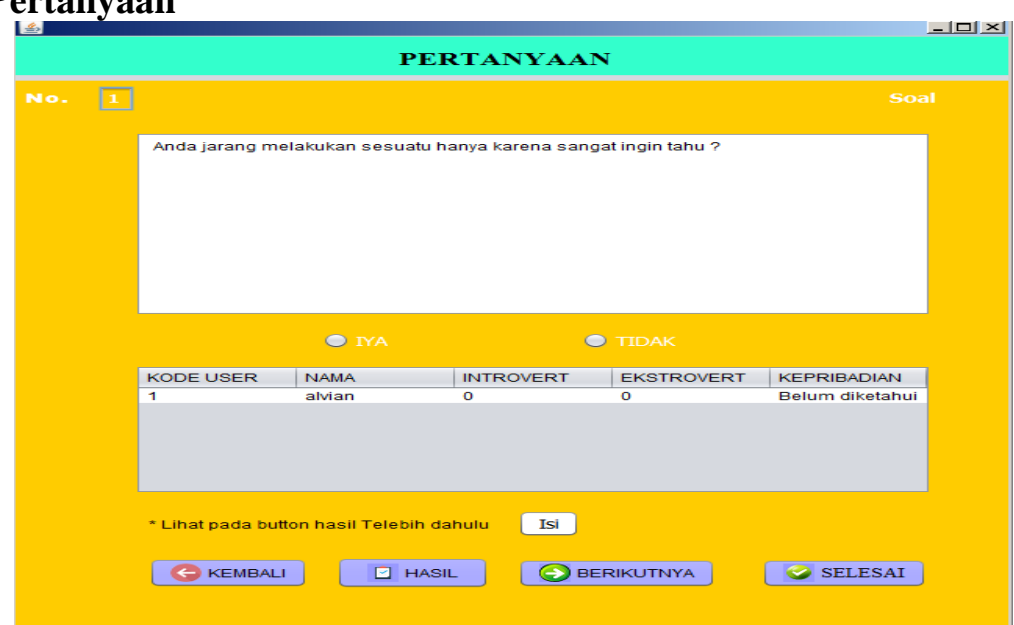

Gambar 7. Tampilan Tes Pertanyaan 
Pada tampilan ini merupakan rancangan tampilan form tes pertanyaan. Berfungsi peserta menjawab pertanyaan yang ada di form.

\section{Tampilan Hasil Tes}

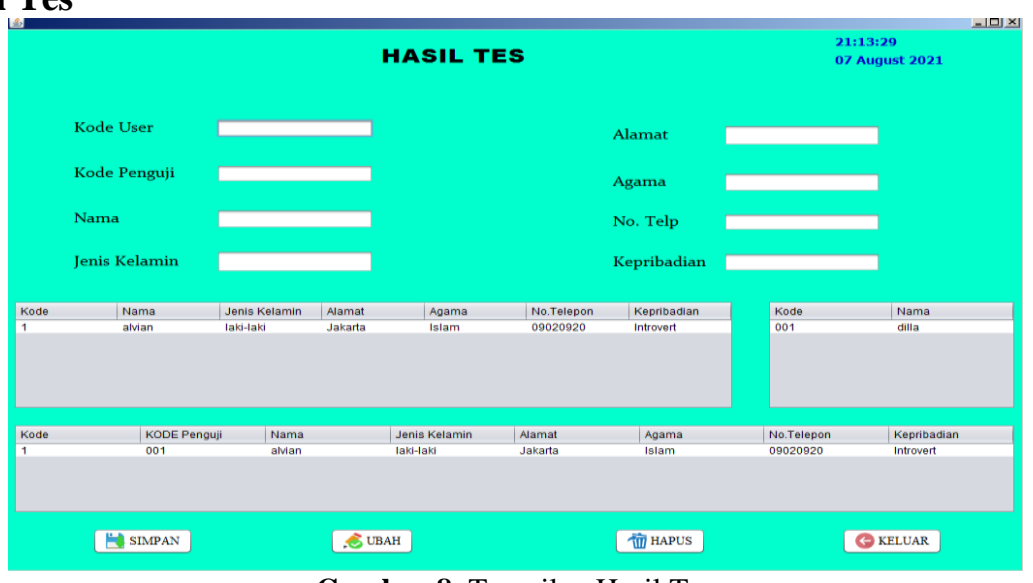

Gambar 8. Tampilan Hasil Tes

Pada tampilan ini merupakan rancangan tampilan form hasil tes. Berfungsi memasukan hasil tes peserta yang sudah menjawab pertanyaan.

\section{Tampilan Arahan}

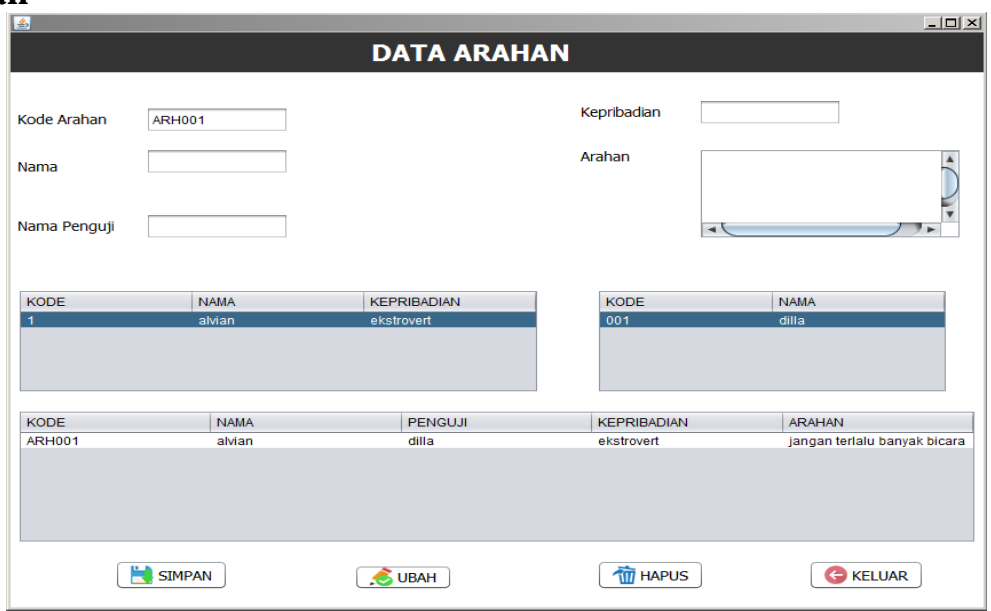

Gambar 9. Tampilan Arahan

Pada tampilan ini merupakan rancangan tampilan form arahan. Berfungsi untuk penguji memberikan arahan kepada peserta.

\section{Tampilan Laporan Data Peserta}
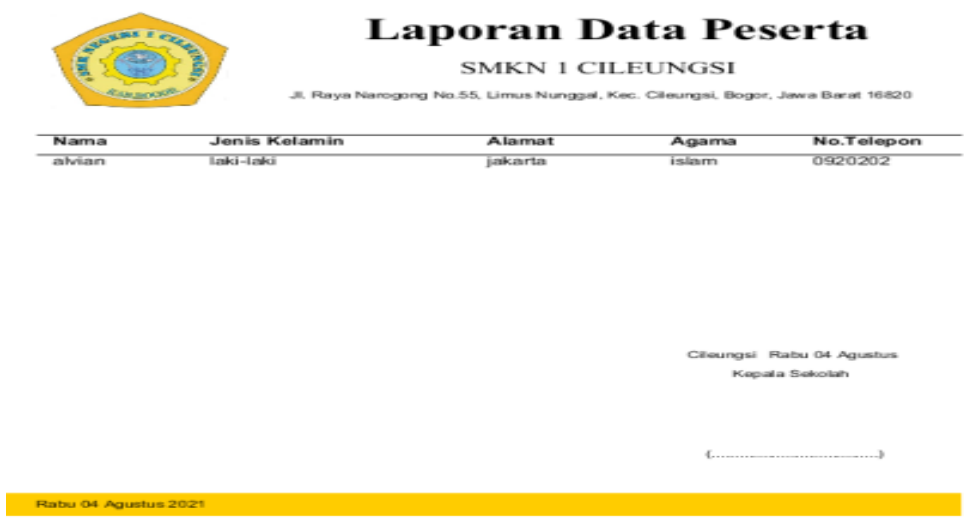

Gambar 11. Laporan Data Peserta 
Tampilan ini merupakan laporan data peserta yang dijadikan laporan setiap peserta mengikuti tes.

\section{Tampilan Laporan Data Penguji}
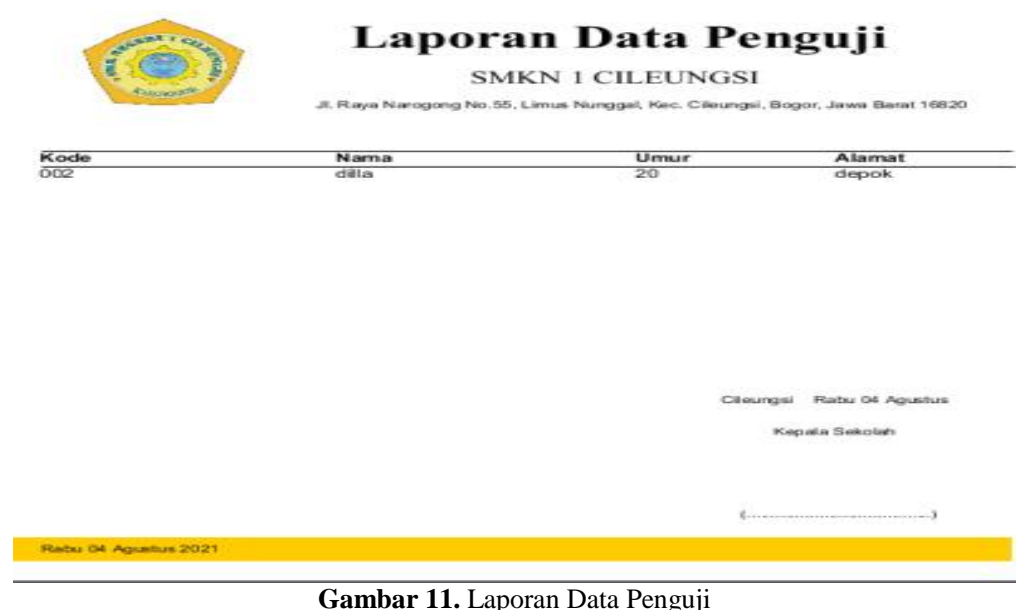

Tampilan ini merupakan laporan penguji yang dijadikan laporan setiap peserta mengikuti tes.

\section{Tampilan Laporan Hasil Tes}
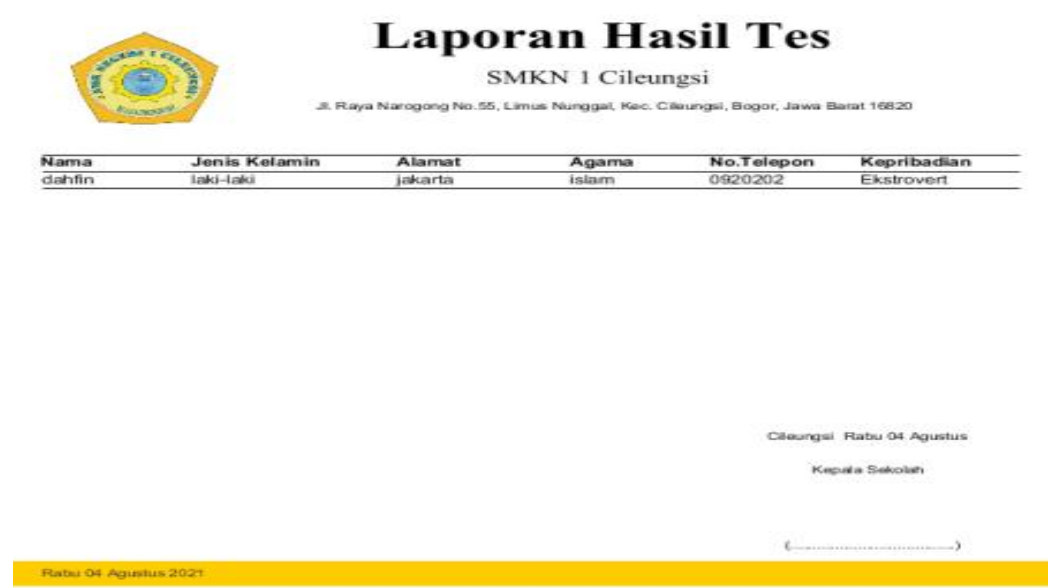

Gambar 12. Laporan Hasil Tes

Tampilan ini merupakan laporan hasil tes yang dijadikan laporan setiap peserta mengikuti tes

Tampilan Laporan Arahan
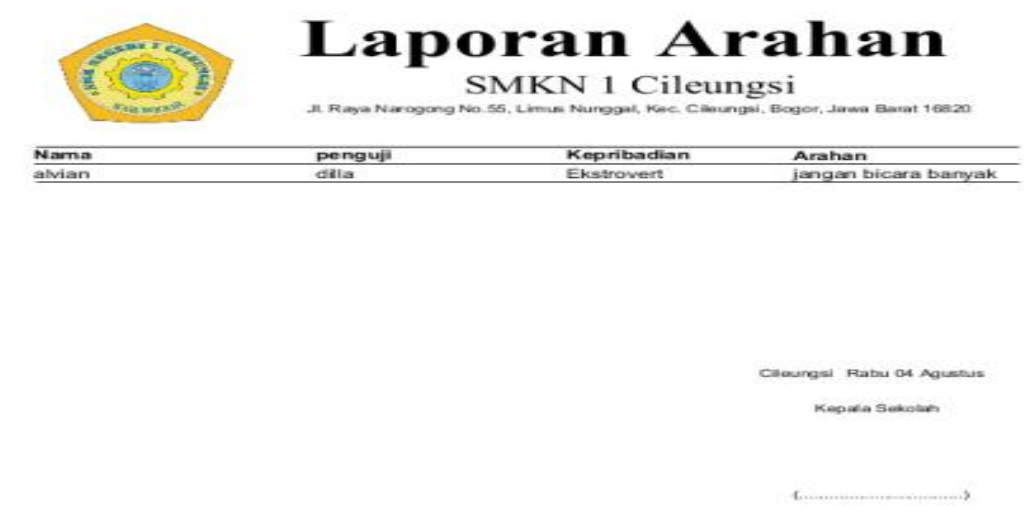

Gambar 13. Laporan Arahan 
Tampilan ini merupakan laporan penguji yang dijadikan laporan setiap peserta mengikuti tes

\section{SIMPULAN}

Berdasarkan dari hasil penelitian yang berjudul "Perancangan aplikasi sistem pakar kepribadian untuk mengidentifikasi sifat dan kepribadian siswa SMKN 1 Cileungsi Berbasis Java Netbeans" adalah dengan dibangunnya perancangan aplikasi sistem pakar kepribadian berbasis java, maka tes kepribadian dilakukan tidak secara manual lagi. Dengan adanya perancangan aplikasi sistem pakar kepribadian pada SMKN 1 Cileungsi dapat memasukan data peserta, data penguji, pengeditan data, penyimpanan data, serta laporan data peserta, data penguji, data hasil tes dan arahan, sehingga proses dapat dilakukan dengan cepat dan efisien.

\section{DAFTAR PUSTAKA}

[1] Asropudin. (2013). KamusTeknologi Informasi Komunikasi. Bandung: CV Titian Ilmu.

[2] Budi Kurniawan. (2011) Aplikasi Sistem Pakar Berbasis Web Untuk Diagnosa Penyakit Gigi dan Mulut

[3] Chan, Syahrial. (2017). Membuat Aplikasi Darabase dengan PowerBuilder 12.6 dan MySQL.

[4] Yossi, Anna Arios. (2018). Perancangan dan Pembuatan Aplikasi Sistem Pakar Analisa Kepribadian Berdasarkan Tes MBTI Berbasis Web

[5] Nafisah, Syifaun. (2010). Grafika komputer dengan Borland C++ builder professional. Yogyakarta:Graha Ilmu

[6] Safaat H, Nazruddin. (2011). Pemrograman Aplikasi Mobile Smartphone dan Tablet PC Berbasis Android.Informatika Bandung: Bandung.

[7] Subagyo, P.J. (2011) Metodologi Penelitian Dalam Teori Praktek. Jakarta: Aneka Cipta.

[8] Subhan, M. (2012). Analisa Perancangan Sistem. Yogyakarta: Andi Offset.

[9] Sutojo, T., Edy mulyanto, Vincent, (2011), Kecerdasan Buatan, Andi Offset, Yogyakarta.

[10] Sugiyono. (2012). Metode Penelitian Kuantitatif Kulaitatif dan R\&D. Alfabeta. 